\title{
Impact of Celebrity Endorsements on Brand Loyalty in Sports Products
}

\author{
Sook Fern Yeo, Cheng Ling Tan, Mei Ling Goh, Heng Yet Toh
}

\begin{abstract}
This research paper studies the drives of the student into cyber entrepreneurial intention. Researching in this topic will help students more understand the factors that influence their brand loyalty. This research paper has focused on six factors that can affect the people brand loyalty. The factors are price, brand image, perceive quality, trustworthiness, attractiveness and expertise which were being researched in past research. The reasons to research on these factors are to investigate the changes in the past few years. Data $(N=189)$ was collected via questionnaire to the respondents and carried out in Malaysia. The data collected are analyzed using SPSS and SmartPLS. Based on the result, there is two independent variable that had a significant relationship with brand loyalty toward sports product in Malaysia which are brand image and price. While the perceived quality, expertise and trustworthiness do not have the significant relationship with brand loyalty. There is a lot of improvement and recommendation that suggest for future study to discuss this topic in deeply.
\end{abstract}

Index Terms: loyalty; celebrity endorser; quality; trustworthiness; brand image; Malaysia.

\section{INTRODUCTION}

Nowadays, sport has a lot of impact on our daily lives and our society. Every day news, information, knowledge, topic that related sport are surrounds us. The power of sport already influences the daily lives of people no matter athlete or not many of country invest a lot of money to promote the development of sports and they know the impact of sport have a lot of potential. Sport are not only impact on personality and it also impact some country's reputation. After World War II, many countries seen sport as a new generation of war that can help them to gain reputation, money, and some of the benefit. The Olympic Games are well known as the most important sport event in the world and the influence of sports can be clearly reflected in the Olympic Games, many of countries fight to become the host countries of Olympic and they know they can gain a lot of benefit from that. Based on the research on the Forbes, the projected final estimated cost of 2016 Rio Olympic Game cost over 11 Billion USD (Settimi \& Christina, 2016) and it also attract an average of 27.5 million primetime viewers in the United States via NBC. In this statistic, the research found sport industry is very potential and influence in people's life. In 2016 NBA had attract 31.02 million viewers to watching the final game and 44.51 million

Revised Manuscript Received on September 22, 2019.

Sook Fern Yeo, Faculty of Business, Multimedia University, Malaysia. tanchengling@usm.my

Cheng Ling Tan, Graduate School of Business, Universiti Sains Malaysia

Mei Ling Goh, Faculty of Business, Multimedia University, Malaysia

Heng Yet Toh, Faculty of Business, Multimedia University, Malaysia viewers in the last 10 minutes of the game. In past 18 years, it was the first basketball game to attract more than 30 million viewers.

The success of the sport cannot do without the sponsor, and most popular sponsor was the company that selling the sport product. Based on the research on the ESPN, NIKE become the sponsor of the NBA jersey and beginning with 2017-18 season and this contract is worth roughly 1 Billion USD. NIKE also well known as a sport company in the world, and it spend the huge number of costs to sponsor NBA is because they know the impact of the sport. Other sponsor done by the NIKE is sponsor the sport equipment for the player, not only NIKE, other company like Adidas, Under Amour, Li Ning also sponsor the sport equipment for the player. Keep update the technology that use in the sport wear, and the work together with those players to get the breaking point in the sport product. These company also promote these products to the fans and let them know the important of the sport wear. Therefore, these company found the sport star as them endorsement to help them boots the sales on the sport product

Marketer nowadays believe the celebrity endorsement is more effectively to attract the attention from the consumer. This mainstream method in the market, the consumer believes those celebrities endorsement of the product has a certain degree of credibility from necessities of life, to luxury goods. The halo effect of the superstar that help the company improve their image and help them to keep the brand loyalty from the consumer. For example, Nike which is the most success the company that using celebrity endorsement to promote their product. In 1984, Nike looked Michael Jordan to endorse their basketball shoe. The Nike use the influence of celebrities to attract a lot of loyal customer until today. Besides that, Adidas look Stan Smith as their celebrity endorsement until today the Adidas Stand Smith was accepted by a lot of customers. A side from the classic example, Adidas partnership with the Famous rapper Kanye West to launch the collection of sport footwear "Yeezy" with the deal cost 10 million.(Henry, 2016) Based on the research that founded, the effect of Kanye West is boots the sales of Adidas. In 2012, Adidas's annual sales was 14.883 Billion, after Adidas launch the collection of "Yeezy" in 2015, the annual sales of Adidas were increase 2 billion.(Dexter Adams, 2016).

\section{LITERATURE REVIEW}

This section started with a literature review on the concept of $R \& D$ project performance. It is then followed by the underlying essence of organizational creative climate that sets the foundation as a 
strong determinant to increase the R\&D performance. After that, the review of many knowledge management literatures is narrowed down to the knowledge acquisition capability in the R\&D project-oriented organizations. This study, finally, develops a link between organizational creative climate, knowledge acquisition capability, and the performance of $\mathrm{R} \& \mathrm{D}$ projects.

\section{A. Brand Loyalty}

Brand loyalty represent the dependent variable in this study. It used to measure the relationship between celebrity endorsement and band loyalty. Brand loyalty can be defined as 'a deeply promise to repurchase a product or service often in future with same brand or company although the situation Different author also has a different defined with brand loyalty "This situation reflects how a consumer be loyal toward a brand, even the company makes a change, either in price or in product features" (Aaker, 1991). The first second approach in the literature is argue with the first approach, this approach defines the behavioral that constantly purchase with same brand or company does not equal with brand loyalty. The reason that company focus establish the brand loyalty among consumer is because businesses can earn more revenue and customer referrals by binding customer loyalty.

Today, a business or company able to gain more benefit through establish the brand loyalty. A good relationship with the consumer will help the company build the customer loyalty and it also bring a lot of benefit to the company. It can help the company or business to increase the market share and become more competitive in the market. Increase the market share and competitive advantage are important to a company or business because it help the company to fight against the competitors. The capital that need to invest to attract the new customer is five time more than attract exists customer. Mean that, business is able to invest less capital to the product if there have exists customer based. The new customer will be finicky than old customer because they haven't built the mind set with the intense brand loyalty toward the company. The higher capital that company need to invest to develop the product since there are lower brand loyalty among the consumers. (Malik, et al., 2013) Business will try their best to make strong relationship with customer and improve the customer satisfaction because the brand loyalty is one of the goals of a company. Besides that, brand loyalty can be explained as the level loyalty between consumers and specific brands or product, even though there are many existing competitor brands. Brand loyalty also happened when the consumer meets the product that fits the customer's requirement. Then, the idea will be created in the customer's mindset, and the brand loyalty has become the basis of customer purchase intention. A lot of people will stick with the brand or product that they are trusted, rather than seeking for a new brand or product in the market. The customer base are become a part of asset for the company, because the customer are willing pay the higher money for the product that they are trust (Yee \& Yahyah, 2009). and marketing efforts may lead to conversion' (Oliver, 1997). approach in marketing literature is behavioral loyalty toward who constantly purchasing a specific or single brand. The

Nowadays, business is willing spend more money to build the relationship with the consumer. The stronger relationship with customer will bring a lot of potential benefit for the company. Celebrity endorsement is one of the strategies that successfully publicity stunt to persuade consumers and to obtain positive impact on company financial result (Chaudhary \& Asthana, 2015). .By this way, the company not only gain the brand loyalty from the customer, and it also help the company that gain a lot of potential customer form the market.

The business should improve the perceive quality of the product, because the perceive quality of the product has a great influence on consumer loyalty (Kinuthia et. al., 2012) Consumers may repurchase the single brand or changing several brand due to the perceive quality of the product. Besides that, according to Yee and Yahyah (2009), price may be the most important issue affect the consumer purchase intention. Customer's loyalty and satisfaction can be created based on the perceived costs and value. If the price is higher than the perceive value of the product, the customer will bot purchase the product. It was important due to the consumer who want to avoid the risks, they are willing to pay higher price toward the brand they are trust.

Due to the research by Aaker (1991) customers may more believe the more famous brand names than the unfamiliar ones. The familiar brand image and name will attract the consumer to purchase and repurchase with the brand. There is positive relationship between brand image and brand loyalty (Sung, Kim, \& Jung, 2009; Ming, Ismail, \& Rasiah, 2011). The trustworthiness was relating the level of trust of a source. The trustworthiness of the endorser's is depending on the viewer's perception on the endorser's intention (Munyau \& Mwirigi, 2013). The expertise can be explain as the knowledge, experience or the skill possessed related the brand or product. There is more expertise have been found, there are more easy to persuasive and generate the purchase intention of customer.

\section{B. Brand Image}

According to Keller (1993) brand image can be defined as the image of a brand that bring to the customer's mind. Discover brand image also define as an important factor in marketing. The branding strategies create the brand image and brand identity, and the strategies was successful because it helps to improve the brand identity. Set an easy and unique brand name is one of the strategies to assist to create a stronger, unique and long-lasting image to consumer's mind. Brand image also is the important assets toward a business, which represent the value and the characteristics (Patker \& Mateen, 2016) about the product. Besides that, consumer's feeling toward the brand also can be define as brand image (Roy \& Banerjee, 2007). A research who done by (Aaker, 1991), he mentions that, brand loyalty related the uniqueness of a brand to customer. A strong brand image will create brand of high-quality brand reputation over the competitive brand. Furthermore, (Burmann, Schaefer, \& Maloney, 2008) found the brand image will affect the customers' purchase intention. 
According the past research done by Richardson, Alan, and Arun (1994) the overall of the perception of uniqueness product will affect the behavior of customer, customer will think the higher brand image may be the good quality and value. Meanwhile good quality and good value of a brand or product will improve the image of the brand; good image of brand will increase the brand loyalty of consumer. Another word, the perceive quality and value will positive effect the brand image. Brand image will direct affect by percepts quality and value. This set of concepts was an important issue in the consumer' purchase intention when consumer compare with other brand. (Sung, Kim, \& Jung, 2010) found brand image have a positive relation with brand loyalty. The brand image was strong, the consumer will be more loyal toward the brand or company. Besides that, according the past research that done by Ming et. al. (2011) mention the brand image have positive image with brand trust. Meanwhile the stronger brand image of the company or brand, will let the higher brand trust and loyalty

Brand image is the most complex issue. It affects the customer loyalty because customer prefer the image to present them self. This may happen both at the level of consciousness and subconscious (Kinuthia, 2012). Brand image also can be defining as the durability of a brand that insert to customer memory (Aaker, 1996). Mean the brand image presenting the massage or image that related the brand, and the durable of the memory. The company that have a good image, can insert memory to the customer with long time. It also can be defining as customer can remember the information or massage of the brand, because the brand image is strong.

\section{Perceived Quality}

Perceived quality can be defining as the judgment of the customer about overall of the product (Zeithaml, 1988). According to Aaker (1991) the customer's the overall quality of the product or service perception by the customer. The overall components of product of consumer's perception also can be define as perceived quality of the product. Besides that, perceive quality can be separate as difference between overall quality and undetected quality. Chaudhuri and Asthana (2015) meantioned that customer satisfaction will lead by the perceived quality because it determined by the perceived performance and expectation. Perceived quality will affect the customer satisfaction, it determined by the overall of expectation of the product or the brand.

Perceived quality also offer value to a brand in several ways; customer will buy the brand base on the high quality had been given and it increase the differention with other competitors. It also helps the company to charger a premium price and have a strong basis for increase the opportunity (Aaker, 1991). Besides that, perceived quality also can have defined as the customer's expectation from the quality of product. Perceive quality have been found to be the main issue effect the brand image (Ming et al. , 2011) According to Biedenbach and Marell (2009) brand loyalty will be affect by the perceived quality. If the perceived quality is good, the brand loyalty among the customer will be stronger. The behaviour of the repurchase of single brands will due to the tangible quality of the product (Kinuthia et. al., 2012). The tangible quality of the product will affect the brand loyalty of the customer.

The perceive quality is not the real quality of the product, but it is the consumer's subjective evaluation of the product (Erenkol \& Duygun, 2010). In other word, perceive quality is the overall quality that customer judge and idea toward the product. Based on Yoo, Donthu and Lee (2000) perceived quality is a part of brand value, which is leading the purchase intention of the customer, and choose the brand better than another competitor. The reason that customer will choose the brand is because the perceive quality of the product is better than other competitor, perceive quality have affect the buying behaviour of customer. The perceive quality of the product will positive impact to the brand loyalty. Besides that, the perceive quality also will impact the purchase intention of customer; the higher perceive quality of product, the stronger purchase intention of customer.

\section{Expertise}

Endorser expertise is considered as the ability to make the sources valid as find out by consumers (Hovland, Janis, \& Kelly, 1953). The celebrity endorser will be likely to consider as an expert if he or she has the relevant knowledge and skills (Homer, \& Kahle, 1990,). Besides, a celebrity with high expertise will be an expert endorsement while the celebrity with low expertise is seen as a typical endorsement. Expertise is the knowledge on product of the endorser and this will increase the reliability of the celebrity endorsement product. Besides, it is believed that expertise of endorser is the factors that will increase the trustworthiness (Silvera \& Benedikte Austad, 2004). It is the main factor to affect purchasing intention which is celebrity expertise. (Goldsmith, Lafferty, \& Newell, 2000) defined celebrity expertise is the knowledge related to the topic and can be trust. Expertise is the crucial component in the celebrity credibility. When consumers try to assess the expertise of celebrity, it will reflect on the justifiability of the celebrity and the celebrity intention to present the reliable statement. There is claimed that the more consumer trust the information, the more the celebrity is considered to be more reliable and thus the consumer will more trusted on the product information(Ohanian, 1990). It is concluded that the source reliable is seen to have the positive impact on the consumer behavior. Therefore, the product sources are trustable, and thus the meaning is believable too (Goldsmith et. al., 2000).It can be said that if the celebrity is creditability, the product they endorse will be gain the advantage of the celebrity.

The impact of endorsers was recognized by two difference characteristic which is reliability and similarity with consumer (Friedman \& Friedman, 1979). It is suggesting that expertise of endorsers will influence the consumer through the process of endorse the product while the typical endorser will fail during the process. Furthermore, it is argued that if endorse is endorse a particular product, it will not have the same effectiveness for other types of products. Therefore, the expert endorses is recommend endorsing the product which is more expensive while the typical endorser can endorse the everyday products. According to Wang (2005), he has design a paper which to study the

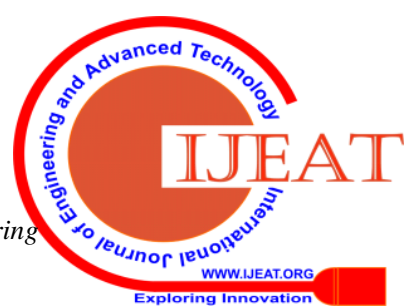


effect of expert and typical endorsement on consumer's response. This paper is to explore the difference power of expert endorser and typical endorser on experiential products (Wang, 2005). The result showed that typical endorser is less effective than expert endorser on the high-technology product (Biswas, Biswas, \& Neel, 2006). Based the research on celebrity endorsement, it is claimed that endorser expertise is a significant component in examining the effect of match-up (Ohanian, 1991). According to paper developed by Till and Busler (2000), it examines the match-up impact with different relevant characteristic. If the celebrity has the product expertise, it is seeming to be a beneficial information to audience. If consumers claimed that the source and information is trustworthiness as expert endorser, they are likely to buy the product.

A celebrity possesses more expertise is considered to motivate more buying intention of consumer than non-expert. According to the study of Ohanian (1991), it is found that expertise of celebrity is crucial in motivate the purchasing intention of respondents. Besides, it is said that the greatest drive of consumer to purchase a brand is endorser's expertise and trustworthiness. Endorser's expertise is the main source that will influence the consumer to buy the product. A celebrity that is claimed to be more expertise will able to generate the more buying intention of consumers (Ohanian, 1991)

\section{E. Trustworthiness}

Trustworthiness means honesty and the ability to trust of something. The customer's trust is depending on the endorsers' intention. According to Shimp (2010) if the potential customer think that the endorsers is driven by their own personal interests, they will not easily have persuaded. Thus, customers will view celebrity endorsers as untrustworthy regardless of the quality of the products and where the message come. When consumers trust that the source is trustworthy, they will assumed that the message bring from the endorser is reliable. Furthermore, endorsers must be objective during their presentation but not try to control the audience. (Shimp, 2010) Besides, the endorsers are considered to be trustworthy if they have matches the favorable characteristic from the audience, they can even promote a more beneficial attitude towards the brand. (Shimp, 2010) Therefore, the marketers must be very cautious when selecting the endorsers, the endorsers must be honest and dependable in order to improve the value of reliable.

Brand trustworthiness is considered as the reliability of the message conveyed by a brand. Existing research illustrate that brand trustworthiness will influence the consumers' when make choice on brand (Erdem \& Swait, 2004) and also will make the consumers become less extreme on the price (Erdem, Swait, \& Valenzuela, 2006). According to Wang, Kao and Ngamsiriudom (2017) to study the relationship between endorser's trustworthiness, brand manner, brand trustworthiness and the buying intention through celebrity endorsement idea. This paper is using the questionnaire survey method to collect the information and generate hypothesis based the existing literature. The result shows that there is positive relationship exist among all the hypothesis. Therefore, it is important to having an appropriate endorser because it will boost the brand manner, brand trustworthiness and the buying intention of consumers. If the brand has high level of trustworthiness, the consumer will not become aware of the risk and thus will decrease the decision-making cost by consumers. Therefore, the firm can build up the brand trustworthiness by deliver the quality information through advertising.

There is a direct relationship between the endorser trustworthiness and brand equity of consumer. It is claimed that the celebrity endorsement will influence the brand recognition because the celebrity endorser is act as a connecting point between consumer's memory and brand name. It is said that a highly trustworthiness endorser will strongly have related to the brand in consumer's mind (Biswas et. al., 2006). Many researchers promote to use another way to improve the brand image by using celebrity endorsement (Keller, 2005) When there is a celebrity endorsement, the consumers may not only will related the celebrity with the brand but also will related the celebrity to the endorsed brand. Lastly, the celebrity endorsement will influence the quality of the brand that perceived by consumer. The celebrities will act as a external hint to convey the message of the product and reduce the consumer's uncertainty and thus boosting the product preference (Dean, 1999).

Many firms believed that using celebrity endorsement will influence the brand recognition in consumer's mind no matter they are existing consumer or potential consumer and no matter what they experienced with this brand. According to paper carries out by Ogunsiji (2012). This paper is to study the impact of celebrity endorsement on the brand, which the endorsement effectiveness is depend on the attitude of the endorser. The most significant aspect in celebrity endorsement is trustworthiness. This statement had been agreed when Infirmarian find a brand and advertisement. Most experts claimed that in order to promote a product or services, it is important to having a reliable and expertise of that product and services (Ogunsiji, 2012)

In China, celebrity endorsement is a noticeable strategy where a national celebrity always endorses more than twenty brands. There is a trend of using celebrities in advertising in the marketplace in both United State and China, the celebrity endorsement is considered as the crucial key strategy to promote the brand (Chan, 2008). According to the research conducted by Chan (2008), it is to study the issues which celebrity endorsement will influence the purchase intention. This paper is using questionnaire survey where respondents come from different countries. It is shown that celebrity endorsement is important to boost the purchase intention. The researcher claimed that the entertainment-based component will examine the satisfaction of a person who adore the celebrity.

\section{METHOdOLOGY/MATERIALS}

This study used the purposive sampling and the unit analysis for this study is undergraduates in Malaysia higher education. A self-administered questionnaire was used in this study. A total of 200 questionnaires were distributed to the targeted 
respondents in Malaysia. The survey was collected between December 2017 and February 2018. Using the drop-off, pick-up method, the researchers visited those approved higher learning institutions in to explain the purpose of the survey to the respective University authorities and to later collect the responses.

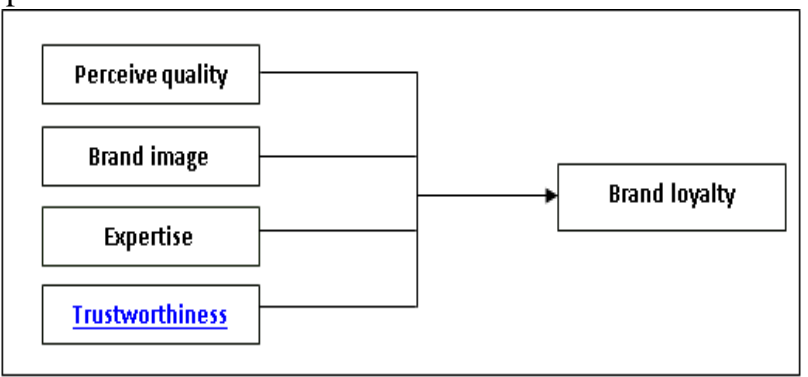

Fig 1. Research framework

\section{RESUltS AND FINDINGS}

The total survey that sent was 200 , but the respondents were only 189 . Based on the 189 of respondents which included 84 of females and 105 of males. The females conduct $44.40 \%$ and males conduct $55.60 \%$. Therefore, there were only 189 respondents involved and so the response rate is $94.5 \%$. Out of the 189 respondents which had involved in respondent that involved in this study were male which contain $55.6 \%$ whereas female only had $44.4 \%$. It indicated that the number of male respondents is more than female respondents. Next is the age category. Most of the respondent are age range between 19-20 years old have 84 respondents, and the age range between 23 or above are the least which contain 11 respondents. Besides that, the age range between 18 or below have 46 respondents, and age range between 21-22 have 48 respondents. For the percentage, age range between $19-20$ contain $44.40 \%, 24.3 \%$ were the age 18 years old and below, 25.4\% age between 21-22 years old and age range between 23 and above only 5.8\%. In conclusion, most of the respondents were age range between 19-20-year-old. Besides, there are 98 respondents are study in business faculty and remain 91 respondents were not study in business faculty. For the percentage, there are $51.9 \%$ of respondent are study in business and $48.1 \%$ of respondent are not study in business faculty. The most of respondent is study in business faculty.

On the other hand, there are 29 of respondents were get from their parent between RM501-RM800, 87 of the respondents get RM1001-RM1500 from their parent,58 of the respondent are get RM801-RM1000 per month from their parent and 15 of respondents get more thanRM1500 from their parents. For the percentage, $46 \%$ of respondents were get RM1000-RM1500 per month, and $15.3 \%$ of respondents were only get RM501-RM800 form their parents,30.7\% of the respondents were get RM801-RM1000 from their parent and only $7.9 \%$ of respondents get more than RM1500 per month. As conclusion, most of the respondents are get Rm1001-RM1500 from their parents. Furthermore, there were 67 of respondents engage in part time, and there were 122 of respondents do not engage in part time. For the percentage, there were $35.4 \%$ of respondent who engage in part time and $64.6 \%$ of respondents were not engage in part time. this survey, include 84 females and 105 males. Most of the

\section{A. Measurement model}

The first step in PLS-SEM analysis is to evaluate the measurement model in order to determine how well the items load on the hypothetical construct. This involves examining the reliabilities of the indicators, the latent variables, internal consistency (Composite Reliability), and construct validity (loadings and Average Variance Extracted) as well as discriminant validity (Fornell-Larcker criterion and Heterotrait-Monotrait ratio). Table 1 reveals that the measurement model has adequate construct validity as suggested by Hair et al. (2010).

TABLE 1 VARIANCE INFLATION FACTOR, LOADINGS, COMPOSITE RELIABILITY, AND AVERAGE VARIANCE EXTRACTED

\begin{tabular}{|c|c|c|c|c|}
\hline Constructs & Items & $\begin{array}{l}\text { Loadin } \\
\text { gs }\end{array}$ & $\begin{array}{l}\text { Composite } \\
\text { Reliability }\end{array}$ & AVE \\
\hline \multirow{5}{*}{ Brand Image } & BI1 & 0.879 & \multirow{5}{*}{0.932} & \multirow{5}{*}{0.732} \\
\hline & BI 2 & 0.896 & & \\
\hline & BI 3 & 0.867 & & \\
\hline & BI 4 & 0.864 & & \\
\hline & BI 5 & 0.764 & & \\
\hline \multirow{5}{*}{ Brand Loyalty } & BL1 & 0.855 & \multirow{5}{*}{0.914} & \multirow{5}{*}{0.681} \\
\hline & BL2 & 0.847 & & \\
\hline & BL3 & 0.796 & & \\
\hline & BL4 & 0.802 & & \\
\hline & BL5 & 0.825 & & \\
\hline \multirow{3}{*}{ Expertise } & EXPERT1 & 0.976 & \multirow{3}{*}{0.882} & \multirow{3}{*}{0.717} \\
\hline & EXPERT 2 & 0.755 & & \\
\hline & EXPERT 3 & 0.792 & & \\
\hline \multirow{4}{*}{$\begin{array}{l}\text { Perceived } \\
\text { Quality }\end{array}$} & PQ1 & 0.757 & \multirow{4}{*}{0.834} & \multirow{4}{*}{0.556} \\
\hline & PQ 2 & 0.712 & & \\
\hline & PQ 4 & 0.788 & & \\
\hline & PQ 5 & 0.725 & & \\
\hline \multirow{3}{*}{$\begin{array}{l}\text { Trustworthin } \\
\text { ess }\end{array}$} & TRUST1 & 0.927 & \multirow{3}{*}{0.884} & \multirow{3}{*}{0.721} \\
\hline & TRUST 2 & 0.915 & & \\
\hline & TRUST 3 & 0.682 & & \\
\hline
\end{tabular}

\section{B. Structural model}

The statistical significance of the path coefficients was determined after the bootstrapping analysis. According to Hair et al. (2013) stated that the number of bootstrap samples should be high and exceeded the number of valid observations in the data. Therefore, the bootstrapping procedure used for this study is with 5000 resample. In Table 2, only brand image was supported while expertise (standard beta $=0.014, \mathrm{t}=$ 0.228 ), perceived quality (standard beta $=-0.079, \mathrm{t}=1.341$ ) and trustworthiness (standard beta $=-0.039, \mathrm{t}=0.837$ ) to brand loyalty were not supported.

TABLE 2 Hypotheses TESTING

\begin{tabular}{|c|c|c|c|c|c|}
\hline & $\begin{array}{l}\text { Stand } \\
\text { ard } \\
\text { Beta }\end{array}$ & $\begin{array}{l}\text { Stand } \\
\text { ard } \\
\text { Error }\end{array}$ & $\begin{array}{l}\mathrm{T} \\
\text { value }\end{array}$ & $\begin{array}{l}\mathrm{P} \\
\text { Value } \\
\mathrm{S} \\
\end{array}$ & Decision \\
\hline $\begin{array}{l}\text { Brand Image -> } \\
\text { Brand Loyalty }\end{array}$ & 0.711 & 0.063 & $\begin{array}{l}11.22 \\
1 * *\end{array}$ & 0.000 & Supported \\
\hline
\end{tabular}




\begin{tabular}{llllll}
\hline $\begin{array}{l}\text { Expertise -> Brand } \\
\text { Loyalty }\end{array}$ & 0.014 & 0.061 & 0.228 & 0.820 & $\begin{array}{l}\text { Not } \\
\text { supported }\end{array}$ \\
$\begin{array}{l}\text { Perceived Quality -> } \\
\text { Brand Loyalty }\end{array}$ & -0.079 & 0.059 & 1.341 & 0.180 & $\begin{array}{l}\text { Not } \\
\text { supported }\end{array}$ \\
$\begin{array}{l}\text { Trustworthiness -> } \\
\text { Brand Loyalty }\end{array}$ & -0.039 & 0.047 & 0.837 & 0.403 & $\begin{array}{l}\text { Not } \\
\text { supported }\end{array}$ \\
\hline
\end{tabular}

$* * p<0.01, * p<0.05$

\section{CONClusion}

This study contributes to the impact of celebrity endorsements through perceived quality, brand image, expertise and trustworthiness towards brand loyalty towards sports products. Since, sport product industries have a lot of potential toward a company or association, so this research can help to identify the factor that make the people repurchase and keep them loyalty toward the company. There are a lot of benefit towards a company so that the sport company should pay more attention to develop their product. Not only the product, should company pay more effort to find the way to keep the customer loyalty. Some of the company can refer the data and information from this research before that set their strategic. This can help them to become more effectiveness and efficiency during they are doing the marketing or advertising discussion. Furthermore, company also need to improve the marketing strategic base on this study and improve the endorser's condition. Future research should target on a larger group of respondents throughout Malaysia to improve the actualization of the findings.

\section{REFERENCES}

[1] Aaker, D. (1991). Managing Brand Equity: Capitalizing on the Value of a Brand Name. New York: The Free Press.

[2] Biedenbach, G., \& Marell, A. (2010). The impact of customer experience on brand equity in a business-to-business services setting. Journal of Brand Management, 17, 446-458.

[3] Biswas, D., Biswas, A. and Das, N. (2006). The Differential Effects of Celebrity and Expert Endorsements on Consumer Risk Perception. Journal of Advertising, pp. 17-31

[4] Chan, K. W. (2008). Understanding Celebrity Endorser Effects in China: A Consumer Celebrity Relational Perspective.". Proceedings of GMC Shanghai Conference, forthcoming.

[5] Chaudhary, U. and Asthana, A., (2015), "Impact of Celebrity Endorsement on Consumer brand loyalty: Does it really matter." International Journal of Scientific and Research Publications, 5(12), 220-225

[6] Dean, D.H. (1999), "Brand endorsement, popularity, and event sponsorship as advertising cues affecting consumer pre-purchase attitudes", Journal of Advertising, 28 (3), 1-12.

[7] Erdem, T., \& Swait, J. (2004). Brand credibility, brand consideration, and choice. Journal of Consumer Research, 31, 191-198.

[8] Erdem, T., Swait, J. \& Valenzuela, A. (2006), "Brands as Signals: A Cross-Cultural Validation Study," Journal of Marketing, 70 (January), 34-49.

[9] Erenkol, A. D., \& Duygun, A. (2010). Customers perceived brand equity and a research on the customers of

[10] Bellona which is a Turkish furniture brand. The Journal of American Academy of Business, 16(1), 93-109.

[11] Goldsmith, R. E., Barbara A. L. \& Stephen J. N. (2000), "The Impact of Corporate Credibility and Celebrity Credibility on Consumer Reaction to Advertisements and Brands," Journal of Advertising, 29 (Fall), 43-54.

[12] Homer, P. M., \& Kahle, L. R. (1990). Source expertise, time of source identification, and involvement in persuasion: An elaborative processing perspective. Journal of Advertising, 19, 30-39

[13] Keller, K. L. (1993). Conceptualizing, measuring and managing customer-based brand equity. Journal of Marketing, 57, 1-22.
[14] Keller, K. (2005). Choosing the right brand elements and leveraging secondary associations will help marketers build brand equity". Marketing Management, 14 (5), 19-23.

[15] Kinuthia, L., Mburugu, K., Muthoni, H., Mwihaki, M. (2012). Factors Influencing Brand Loyalty in Sportswear, Asian Journal of Social Sciences and Humanities, 223-231.

[16] Malik, M. E., Ghafoor, M. M., Iqbal, H. K. (2013), Importance of Brand Awareness and Brand Loyalty in assessing Purchase Intentions of Consumer, International Journal of Business and Social Sciences, Vol.4, No.5, p.168.

[17] Ming, T.T., and Ismail, H.B., Rasiah, D., (2011). "Hierarchical Chain of Consumer-Based Brand Equity: Review from The Fast Food Industry". International Business \& Economics Research Journal. Vol,10. No.9: p.p67-80.

[18] Munyau, P.K. and F.M. Mwirigi, 2013. The influence of customer loyalty on celebrity endorser choice decision making: An exploratory survey of customers of selected celebrity endorsed products in Kenya. European Journal Business Management, 5: 86-94.

[19] Ohanian, R. (1991). The Impact of Celebrity Spokespersons' Perceived Image on Consumers' Intention to Purchase. Journal of Advertising Research, Vol. 31, No. 1:46-54.

[20] Oliver, R. (1997). Satisfaction: A behavioral perspective on the consumer. new york: Irwin McGraw-Hill.

[21] Patker, T. A.R. \& Mateen, S. (2016). The impact of brand loyalty on product performance. International Journal of Social, Behavioral, Educational, Economic, Business and Industrial Engineering, Vol:10, No:6.

[22] Richardson, P. S., Alan S. D. \& Arun K. J. (1994). "Extrinsic and Intrinsic Cue Effects on Perceptions of Store Brand Quality," Journal of Marketing, 58 (October): 28-30

[23] Roy, D. and Banerjee, S. (2007), "CARE-ing strategy for integration of brand identity with brand image", International Journal of Commerce and Management, Vol. 17 Nos 1/2, pp. 140-8.

[24] Shimp, T. (2010). Advertising promotion and other aspects of integrated marketing communication. taxes: the Dryden Press, Fortworth,.

[25] Sung, Y., Kim, J. and Jung, J.H. (2009), “The predictive roles of brand personality on brand trust and brand affect: a study of Korean consumers", Journal of International Consumer Marketing, Vol. 22 No. 1 , pp. 5-17.

[26] Wang, A. (2005), "The Effects of Expert and Consumer Endorsement on Audience Response," Journal of Advertising Research, 45 (4), 402-412.

[27] Wang, S. W., Kao, G. H. -Y. and Ngamsiriudom, W., (2017), "Consumers' attitude of endorser credibility, brand and intention with respect to celebrity endorsement of the airline sector", Journal of Air Transport Management, vol. 60, pp. 10-17.

[28] Yee, W. F., \& Yahyah, S. (2009). Influence of Brand Loyalty on Consumer Sportwear. International Journal of Economics and Management, 2 (2), 221-236.

[29] Yoo, B., N. Donthu, S. Lee. 2000. An examination of selected marketing mix elements and brand equity. Journal of Academy Marketing Science. 28(2) 195-211.

[30] Zeithaml, V. A., Berry, L. L. and Parasuraman, A. (1996b). The behavioral consequences of service quality. Journal of marketing,60(2).

[31] Zhang, Y. (2015). The Impact of Brand Image on Consumer Behavior: A Literature Review. Open Journal of Business and Management, $3(01), 58$

\section{AUTHOR PROFILE}

I am Sook Fern Yeo, currently I am affiliated with Faculty of Business, Multimedia University, Malaysia. tanchengling@usm.my

I am Cheng Ling Tan, currently I am affiliated with Graduate School of Business, Universiti Sains Malaysia

I am Mei Ling Goh, currently I am affiliated with Faculty of Business, Multimedia University, Malaysia

I am Heng Yet Toh, currently I am affiliated with Faculty of Business, Multimedia University, Malaysia 